\title{
THE INFLUENCE OF THE AGEING OF RABBIT SPERMATOZOA IN VITRO ON FERTILIZING CAPACITY AND EMBRYONIC MORTALITY
}

\author{
H. H. KOEFOED-JOHNSEN, A. PAVLOK AND J. FULKA \\ Sterility Research Institute, \\ The Royal Veterinary and Agriculture College, Copenhagen, Denmark, and \\ Laboratory of Animal Genetics, Liběchov, Czechoslovakia
}

(Received 5th October 1970)

\begin{abstract}
Summary. Female rabbits were inseminated with spermatozoa which had either been freshly ejaculated or stored for 24 or $48 \mathrm{hr}$ at $5^{\circ} \mathrm{C}$. One oviduct of each female was flushed 26 to $28 \mathrm{hr}$ after insemination and HCG injection. The ova were examined and returned to the same oviduct if cleavage had occurred. This procedure did not affect the subsequent development of the ova, as compared with those in the undisturbed oviduct. The number of implantations was counted at 8 days and the number of live foetuses at 20 days of pregnancy. Compared with fresh spermatozoa, the stored samples showed significantly lower fertilizing capacity and the fertilized ova showed significantly higher pre- and postimplantation losses.
\end{abstract}

\section{INTRODUCTION}

Ageing of spermatozoa in vitro causes a decrease in their fertilizing capacity and an increase in embryonic mortality. This has been amply demonstrated in relation to artificial insemination in cattle by Salisbury \& Flerchinger (1961, 1967). Dziuk \& Hanshaw (1958) and First, Stratman \& Casida (1963) found increased embryonic mortality after insemination with boar spermatozoa which had been stored for $72 \mathrm{hr}$.

Spermatozoa also gradually lose their fertility in the isolated epididymis in vivo, though after a much longer time interval (Hammond \& Asdell, 1926; Tesh \& Glover, 1966). Functional changes evoked by ageing occur rapidly in spermatozoa in the female reproductive tract (rabbits-Hammond \& Asdell, 1926; Maurer, Whitener \& Foote, 1969; Tesh, 1969; guinea-pigs-Soderwall \& Young, 1940).

The aim of the present work was to investigate the fertilizing capacity of rabbit spermatozoa aged in vitro by direct evaluation of ova, and the pre- and postimplantation losses by examination of the uterine contents.

\section{MATERIALS AND METHODS}

Sexually mature females were isolated from males for at least 3 weeks before 
insemination. Semen from six males of known fertility was collected by means of an artificial vagina and investigated microscopically. Ejaculates of good quality were diluted with a tris-egg yolk solution (Koefoed-Johnsen, 1964) to a concentration of 75 to $100 \times 10^{6}$ spermatozoa/ml. An aliquot of the diluted semen was used immediately, and the remainder was cooled to $+5^{\circ} \mathrm{C}$ and stored for 24 or $48 \mathrm{hr}$. The females were inseminated intravaginally with 20 to $40 \times 10^{6}$ spermatozoa. An injection of HGG (Physex-Leo, Copenhagen-10 i.u. $/ \mathrm{kg}$ body weight) was given immediately after insemination. In most cases, two to three females of each group were inseminated with fresh semen, and the same number with semen which had been stored 24 and $48 \mathrm{hr}$, respectively. However, if ejaculates were of inferior quality, the last group of females (semen stored for $48 \mathrm{hr}$ ) was reduced or the ejaculate was discarded.

The females were subjected to laparotomy under ether anaesthesia 26 to 28 hr after insemination, the abdomen was opened by a flank incision on the left side, or by an incision in the linea alba. After checking the ovaries and determining ovulation points on both ovaries, a polyethylene catheter fitted with a glass tube was inserted from the infundibular end into one oviduct to a depth of 1 to $2 \mathrm{~cm}$. With a syringe and a thin needle (No. 20) introduced near the uterotubal junction, the contents of the oviduct were flushed into a watch glass. Two to three ml of medium TC 199, $\mathrm{pH}$ adjusted to 7.5 to 7.8 with sodium carbonate, were used for flushing.

The contents of the oviduct were investigated under a stereomicroscope at $\times 20$ magnification. All cleaved ova were returned to the oviducts by means of a thin glass capillary. The whole procedure was carried out under constant temperature conditions. Uncleaved ova were evaluated under the microscope after fixation with acetic acid: alcohol and staining with lacmoid (Chang, 1952).

Only one oviduct from each female was flushed, the other served as a direct control of the experimental procedure. The females were again subjected to laparotomy 8 days after insemination in order to check the number of implanted embryos and corpora lutea. Twenty days after insemination, the females were killed and their uterine contents investigated.

\section{RESULTS}

The data summarized in Table 1 show the progressive decrease in the fertilizing capacity of stored spermatozoa and the increase in preimplantation losses. The decrease in fertilizing capacity after storage for $24 \mathrm{hr}$ reaches a statistically significant value. A further decrease, though not statistically significant, was found between 24 and $48 \mathrm{hr}$. Embryonic mortality in the preimplantation period also increased with the time of storage in vitro.

The experimental procedures, i.e. flushing of oviducts and return of ova, appeared to have no adverse effect on the further development of the embryos, since the number of implantations expected in the control uterine horns did not significantly exceed the actual implantations in the treated ones.

Table 2 shows the postimplantation losses, including the number of live embryos after 20 days of pregnancy. The dependence on the age of the spermatozoa was also evident here. The differences of postimplantation losses between 


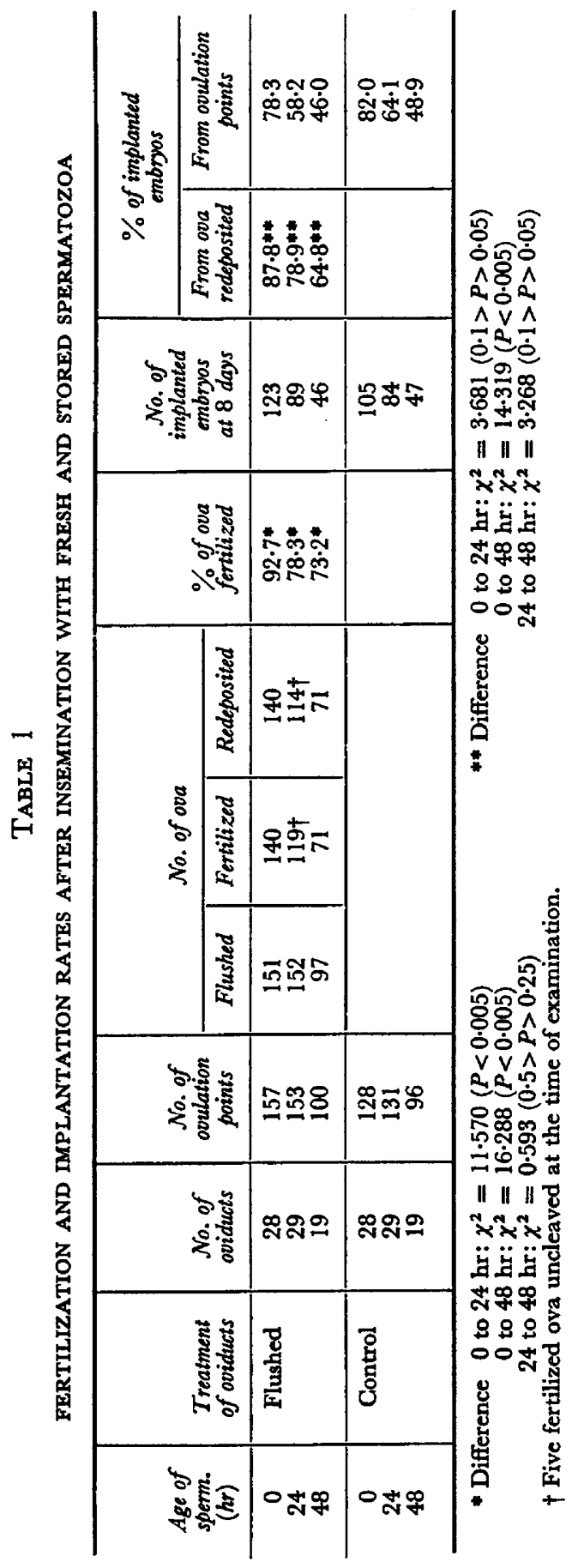




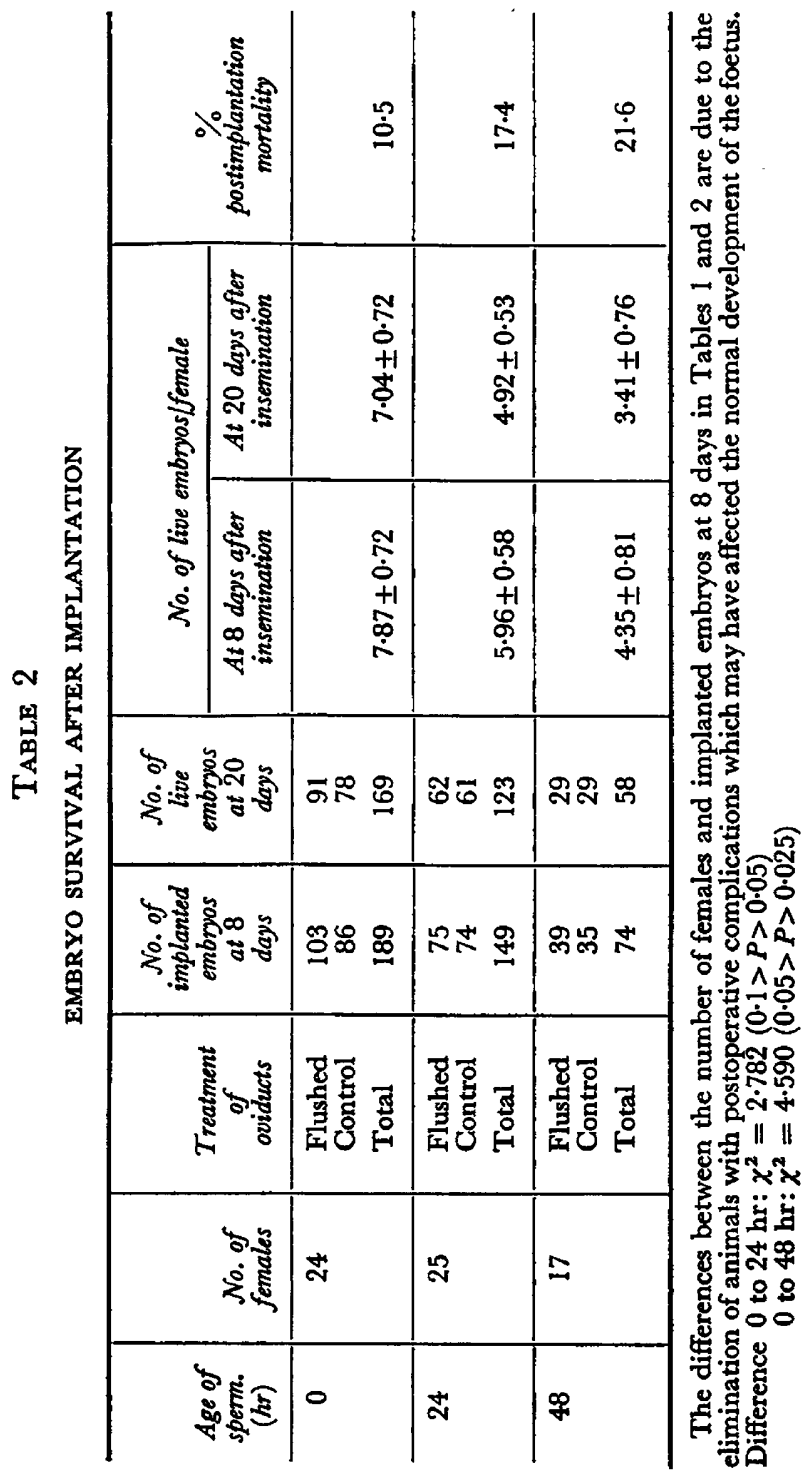


the groups inseminated with fresh spermatozoa and spermatozoa stored for 48 hr were statistically significant, but they did not reach the level of the preimplantation losses.

\section{DISCUSSION}

The changes which occur during the storage of spermatozoa which are responsible for their functional inadequacy are as yet insufficiently known. The original findings of Salisbury, Birge, de la Torre \& Lodge (1961) and more recently of other authors concerning the loss of spermatozoal DNA during storage in vitro have not been fully confirmed (Koefoed-Johnsen, Fulka \& Kopečný, 1968; Miller \& Blackshaw, 1968; Kopečný \& Trebichavský, 1969). Further detailed studies allowed Salisbury (1968) to assume that the changes evoked by ageing affect the spermatozoal DNA or DNP molecule qualitatively rather than quantitatively and may cause damage to the genetic information transfer system.

Spermatozoa stored in vitro can lose their fertilizing capacity to different degrees depending on the storage method used. In our experiments, in spite of the relatively high initial fertility, a decline was observed, which was more rapid than that reported for rabbit spermatozoa by Norman (1964) who used NJ 2 medium, or Miller \& Blackshaw (1968) who diluted ejaculates in IVT medium.

Besides decreased fertility, high preimplantation losses, depending on the period of storage, were observed in the present study. These results are in accordance with those of Maurer et al. (1969), who found that spermatozoa ageing in the female reproductive tract were associated with reduced fertility and cleavage rate, and a lower proportion of embryos developing into blastocysts. In contrast, Tesh (1969) found, for the same type of spermatozoa, reduced fertility only and to a lesser extent an increase of postembryonic losses. He did not observe any effect on preimplantation development. Thibault (1967) described an increased incidence of digyny after fertilization with ageing spermatozoa.

In females with a considerably reduced fertilization rate, especially those which were inseminated with spermatozoa which had been stored for $48 \mathrm{hr}$, the 'undercrowding' effect (Hafez, 1968) may have been one of the causes of higher embryonic mortality.

\section{ACKNOWLEDGMENTS}

The authors are grateful to Dr A. McLaren for reading the manuscript and for her criticism. One of us (J.F.) would like to thank Professor J. Moustgaard, Royal Veterinary and Agricultural College, Copenhagen, for financial support.

\section{REFERENCES}

Chang, M. C. (1952) Fertilizability of rabbit ova and the effect of temperature in vitro on their subsequent fertilization and activation in vivo. F. exp. Zool. 121, 351. 
Dziux, P. J. \& Hanshaw, G. (1958) Fertility of boar semen artificially inseminated following in vitro storage. 7. Anim. Sci. 17, 554.

First, N. L., Stratman, F. W. \& Casida, L. E. (1963) Effect of sperm age on embryo survival in swine. J. Anim. Sci. 22, 135.

HAFEZ, E. S. E. (1968) Fetal survival in undercrowded and overcrowded unilaterally pregnant uteri in the rabbit. Proc. VIth Congr. Anim. Reprod., Paris, 1, 575.

Hammond, J. \& Asdell, S. A. (1926) The vitality of the spermatozoa in the male and female reproductive tracts. Br. 7. exp. Biol. 4, 155.

Koefoed-Johnsen, H. H. (1964) Kunstig saedoverforing hos kaniner. Aarsberetn. Inst. Sterilitetforsk. 7, 33.

KoEFOED-Johnsen, H. H., FULKA, J. \& KopeČNÝ, V. (1968) Stability of thymine in spermatozoal DNA during storage in vitro. Proc. VIth Congr. Anim. Reprod., Paris, 2, 1263.

KOPEČNÝ, V. \& TREBICHAVSKÝ, I. (1969) Resistance of tritium activity in adenine-2,8-T labelled rabbit sperm. Annls Biol. anim. Biochim. Biophys. 9, 463.

Maurer, R. R., Whitener, R. H. \& Foote, R. H. (1969) Relationship of in vivo gamete aging and exogenous hormones to early embryo development in rabbits. Proc. Soc. exp. Biol. Med. 131, 882.

Millek, O. G. \& Blackshaw, A. W. (1968) The DNA of rabbit spermatozoa aged in vitro and its relation to fertilization and embryo survival. Proc. VIth Congr. Anim. Reprod., Paris, 2, 1275.

Norman, C. (1964) Further studies on the preservation of mammalian sperm at variable temperatures. Proc. Vth Congr. Anim. Reprod., Trento, 4, 296.

SAlisbury, G. W. (1968) Fertilizing ability and biological aspects of sperm storage in vitro. Proc. VIth Congr. Anim. Reprod., Paris, 2, 1189.

Salisbury, G. W., Birge, W. J., De la Torre, L. \& Lodge, J. R. (1961) Decrease in Feulgen-positive material (DNA) in in vitro storage of bovine spermatozoa. F. biophys. biochem. Cytol. 10, 353.

SALISBURY, G. W. \& FLERGHINGER, F. H. (1961) In vitro aging of spermatozoa and evidence for embryonic or early fetal mortality in cattle. Proc. VIth Congr. Anim. Reprod., The Hague, 3, 601.

Salisbury, G. W. \& Flerchinger, F. H. (1967) Aging phenomena in spermatozoa. I. Fertility and prenatal losses with use of liquid semen. F. Dainy Sci. 50, 1675.

Soderwall, A. L. \& Young, W. C. (1940) The effect of ageing in the female genital tract on the fertilizing capacity of guinea pig spermatozoa. Anat. Rec. 78, 19.

TEsh, J. M. (1969) Effect of the ageing of rabbit spermatozoa in utero on fertilization and prenatal development. F. Reprod. Fert. $20,299$.

TESH, J. M. \& GLover, T. D. (1966) The influence of ageing of rabbit spermatozoa on fertilization and prenatal development. $\mathcal{F}$. Reprod. Fert. 12, 414.

Thibault, C. (1967) Analyse comparée de la fécondation et de ses anomalies chez la brebis, la vache et la lapine. Annls Biol. anim. Biochim. Biophys. 7, 5 . 